UDC 330.338 .47

DOI: https://doi.org/10.32782/2520-2200/2019-1-17

\author{
Striy Liubov \\ Doctor of Economic Sciences, Professor, \\ Professor of department of Management and Marketing \\ O.S. Popov Odessa National Academy of Telecommunications
}

Stankevich Iryna

Doctor of Economic Sciences, , Associate Professor Head of the Department of Management and Marketing

O.S. Popov Odessa National Academy of Telecommunications

Zaharchenko Lolita

Candidate of Economic Sciences, Professor,

Professor of Department of Enterprise Economics

O.S. Popov Odessa National Academy of Telecommunications

\title{
SYSTEM APPROACH TO RESEARCH OF MODERN MARKETS OF INFOCOMMUNICATION SERVICES
}

The problem of the application of effective scientific approaches to the study of the transformation of the markets of infocommunication services, which are caused by the impact of powerful technological innovations, has been studied. The concepts are clarified: systems approach, markets of infocommunication services, infocommunication services. The following tasks have been set and solved. The possibility and expediency of using a systems approach for the study of modern infocommunication services markets is substantiated. Designed a system model of these markets. The model is a global network that is integrated into the global cyberspace of the Internet. The system organization of the modern markets of infocommunication services is investigated. The following subsystems are considered: infocommunication services consumers; global communications; manufacturers, intermediaries and distributors of information products, Internet companies, media and other Internet agents.

Key words: cyberspace of the Internet, global communications, infocommunications, infocommunication services, model building, system approach.

Изучена проблема применения эффективных научных подходов для исследования преобразований рынков инфокоммуникационных услуг, которые вызваны воздействием мощных технологических инноваций. Уточнены понятия: системный подход, рынки инфокоммуникационных услуг, инфокоммуникационные услуги. Поставлены и решены следующие задания. Обоснована возможность и целесообразность использования системного подхода для исследования современных рынков инфокоммуникационных услуг. Сконструирована системная модель этих рынков. Модель представляет собой всепланетную сеть, которая интегрирована в глобальное киберпространство сети Интернет. Исследована системная организация современных рынков инфокоммуникационных услуг. Рассмотрены подсистемы: потребителей инфокоммуникационных услуг; глобальных коммуникаций; производителей, посредников и реализаторов информационных продуктов, интернет компаний, СМИ и других интернет агентов.

Ключевые слова: глобальные коммуникации, инфокоммуникации, инфокоммуникационные услуги, киберпространство сети Интернет, построение модели, системный подход.

Сучасні ринки інфокомунікаційних послуг схильні до глибинних перетворень в результаті дії потужних технологічних інновацій. Розвиток четвертої промислової революції може викликати істотне прискорення темпів цих перетворень. Виникає необхідність застосування ефективніших наукових підходів для дослідження цих ринків. У статті розглядається проблема дослідження ринків інфокомунікаційних послуг за допомогою системного підходу. Поставлені і вирішені наступні завдання. Уточнені поняття: системний підхід, ринки інфокомунікаційних послуг, Інфокомунікаційні послуги. Обгрунтована можливість і доцільність використання системного підходу для дослідження сучасних ринків інфокомунікаційних послуг. Ринки інфокомунікаційних послуг можна розглядати як складну систему, яка відповідає принципу цілісності, принципу структурності, принципу ієрархічності. Системі ринків властиві: відкритість, цілеспрямованість і керованість, эмерджентность, багатокритеріальність. Тому $є$ 
усі ознаки можливості і доцільності застосування системного підходу для дослідження ринків інфокомунікаційних послуг. При побудові системної моделі ринків інфокомунікаційних послуг був застосований евристичний анаксіоматізаціонний метод, який дозволяє повною мірою використати творчі здібності дослідника, глибоке розуміння їм сутності модельованого процесу. Системна модель ринків інфокомунікаційних послуг є всепланетною мережею, яка інтегрована в глобальний кіберпростір Інтернет. Досліджені підсистеми моделі, виявлені інформаційні зв'язки усередині системи. Особливістю підсистеми споживачів цих ринків $є$ та обставина, що споживачами інфокомунікаційних послуг можуть бути усі відвідувачі Інтернету, усі організації, держава, культура, освіта, армія, усе населення країни. У мережі ринків підприємств комунікаційних послуг працюють практично усі комунікаційні(телекомунікац ійні) підприємства (оператори мобільного і фріксованого зв'язку, інтернет провайдери і інші телекомунікаційні компанії), що функціонують зараз. Підсистема виробників, посередників і реалізаторів інформаційних продуктів включає безліч різних підприємств, що безперервно розширюється : інтернет компанії; підприємства виробники іноормаційних продуктів; підприємства, що тиражують інформаційні продукти; підприємства посередники; підприємства засобів масової інфрормації і багато інших інтернет агенти.

Ключові слова: глобальні комунікації, інфокомунікацій, Інфокомунікаційні послуги, кіберпростір мережі Інтернет, побудова моделі, системний підхід.

Problem statement. Modern markets of infocommunication services under the influence of powerful technological innovations are subjected to profound transformations. The implementation in practice of new communication technologies $3 \mathrm{G}, 4 \mathrm{G}$, (in the future $5 \mathrm{G}$ ) allowed the creation of mobile Internet. Internet access has become possible for a considerably larger number of users with the help of numerous mobile devices. For domestic Internet users it has become possible to choose, purchase and receive on its terminal a large assortment of digital products from any Internet company in the world. In the opinion of K. Schwab, the development of the fourth industrial revolution may provoke an even more significant acceleration of the pace of technological transformation in almost all markets. It is necessary to use more effective scientific approaches to study these transformations. The problem of finding an effective way to investigate the transformation of the markets for infocommunication services through a systems approach becomes relevant and deserves to be studied.

Analysis of recent research and publications. The use of a system approach to research of modern markets for infocommunication services is not yet sufficiently covered in scientific publications. It is possible to note the publications in the scientific journal "Problems of a Systems Approach in Economics" Bagorko M.O. [2] and A.G. Grinenko. [3]. The monograph by T. Kuzovkova [4] reveals the requirements of the economy for the infocommunication infrastructure and the level of development of infocommunications, the laws of the development of infocommunications. The monograph [5] considered the formation of markets for infocommunication services, the requirements that consumers bring to telecommunications companies. In the monograph [6] the properties and differences of infocommunication services are considered, some possible directions of perfection of activity of enterprises of infocommunications are offered. The current state of management of network organizations in the field of infocommunications, the level of competition in markets and the trends in the development of enterprises are investigated in articles [7-12]. At the same time, the problem of using effective scientific methods for studying market transformations under the influence of modern technological innovations is not sufficiently covered.

Purpose of the article. Provide authoring solutions for the following aspects of this problem: to substantiate the possibility and expediency of using a system approach for the study of modern markets for infocommunication services; to design the system model of the markets of infocommunication services; to research the organization of modern markets of infocommunication services.

The main part. Definitions and arrangements. The modern economy and, accordingly, economic science are rapidly changing under the influence of powerful technological innovations. This is especially true for the economy of infocommunication services. In order to eliminate disagreements in the understanding of the material of the article, the wording of the following definitions in the author's wording is proposed.

Definition 1. The system approach is a methodological direction in science based on the development of methods for constructing complexly organized objects and their research as systems. In a systematic study, the analyzed object is considered as a certain set of elements, the relationship of which determines its integral properties. In the process of research, the main emphasis is placed on the identification of the variety of bonds 
and relationships that take place both within the object and in its interaction with the external environment. The properties of an object as an integral system are determined not only by the summation of the properties of its individual elements, but by the properties of its structure, special system-forming, integrative bonds inside and outside the object. The semantic correspondence with [13, p. 103].

Definition 2. Infocommunication services markets are emerging fast-growing markets where products offer, while consumers are asking for fundamentally new products - infocommunication services, in which information products and communication services are integrated into a single whole. In the economy of the XXI century, the field of infocommunication services can become dominant, its advanced development is able to ensure the economic growth of the entire economy and its sustainable development. The demand for modern infocommunication services, the quantity and quality of which constantly increases, in recent years has been maintained at a high level. This results in the rapid development of the markets for infocommunication services. The continuous expansion of the territorial coverage of the Internet through the Internet of all continents and the rapid number of Internet users allows the enterprises of this market to produce innovative services that are necessary for many consumers. This allows you to receive a profit level that ensures expansion of production, development and offering to the market of modern services of the required quality. The semantic correspondence with [5, p. 19].

Definition 3. Infocommunication services arose in the process of convergence of information and communication technologies. Infocommunication services are the result of economically useful labour activity, which has a consumer value and is in demand by the market. These services represent a new reality, in which the goods, information and service are organically linked. New infocommunication services have made it possible to effectively meet the ever-increasing needs of people in a variety of information and modern information products that they experience in the process of economic and other activities. The semantic correspondence with [6, p. 27].

Agreement 1. Infocommunication services markets are characterized by a rapid change in market conditions, and market-based methods must continuously adapt to the real conditions of the market.

Agreement 2. Consumers of infocommunication services are inclined to innovations, an important task of production of these services is their continuous modernization, development and offering of new services to the market.
Agreement 3. In the markets for infocommunication services there is no standardized consumer, all infocommunication services should be personalized.

Justification of the feasibility and expediency of using a systems approach for researching the markets of infocommunication services.

The markets of infocommunication services have all the signs justifying the use of a systems approach for their research. The main ones are as follows.

Each market of infocommunication services, on the one hand, acts as part of a more complex system (the global sphere of infocommunications), and on the other hand, consists of several subsystems: consumers, communications, cyberspace of the Internet, producers, intermediaries, etc. At the same time, the system markets united by a single goal and is holistic (compliance with the principle of integrity).

The behaviour of the infocommunication services market system is determined by its structure - a way of combining the local goals of the subsystems in order to best accomplish the main goal of the whole system (compliance with the principle of structure).

The markets of infocommunication services have a hierarchical structure of the organization, combining centralized management to ensure the fulfilment of the main goal with the autonomy of the subsystems (compliance with the principle of hierarchy).

In addition, the system of infocommunication services markets has:

openness - in the system of markets there is a free exchange of information not only between its constituent elements, but also with a number of other systems, as well as with the external environment;

focus and controllability - the entire system of markets has a common goal and a common purpose;

emergence - in the market system there are integral properties that are not deducible from the properties of individual subsystems;

multi-criteria - there are several criteria for achieving the goal in the market system.

The system of markets for infocommunication services is also characterized by the presence of many internal and external connections between subsystems and elements of the system; the presence of external and internal disturbing factors; competitive and competing parties; the likelihood of conflict situations.

Thus, it is possible and expedient to apply the systems approach methods for researching the markets of information and communication services. 
System model of modern markets of infocommunication services. The modern economy of infocommunication services under the influence of powerful technological innovations is in the process of development, improvement and structuring. This explains the fact that in scientific papers published in different years, different approaches to the construction and description of the markets of infocommunication services are used.

In this article, when building a model of infocommunication services markets, the authors used the review method to study many scientific works of both domestic and foreign authors. These works include monographs $[4 ; 5 ; 6]$, articles [7-12], as well as available publications in Internet sources.

In constructing the model, a heuristic anaxiomatization method was used, which allows you to fully use the creative abilities of the researcher, his deep understanding of the essence of the process being modelled. At the same time, it allows you to reject the irrelevant in order to focus on the essentials [14, p. 553]. Using this method allowed us to solve the problems posed by this study.

The model is presented in the diagram in fig. 1.

The system model of the markets of infocommunication services is a global network that is integrated into the global cyberspace of the Internet. This cyberspace has no national boundaries or limit of its development. Therefore, every Internet user in any country of the world has the opportunity to purchase the necessary infocommunication services [6, p. 98-99].
The diagram shows the model subsystems:

- subsystem of consumers of infocommunication services;

- subsystem of global communications;

- subsystem of cyberspace the Internet;

- subsystem of producers, intermediaries and distributors of information products, Internet companies, the media and other Internet agents.

Separately allocated to the state and institutions.

Research of markets of infocommunication services

Subsystem of consumers of infocommunication services. The peculiarity of these markets is the fact that all visitors to the Internet, all organizations, the state, culture, education, the army, the entire population can be consumers of infocommunication services. This ensures the massive nature of the needs for these services, a steadily growing market demand, but also the need to ensure increased requirements for the quality and forms of the provision of these services. In more detail [6, p. 97].

The information communication of this subsystem and the subsystem of global communications is characterized by the following flows that connect the consumer (client) and the communication company (for example, telecom operator):

$-I_{1.1}$ - information on the provision of digital telephony services (voice communication of the operator's client with any other client via a communication channel), advertising;

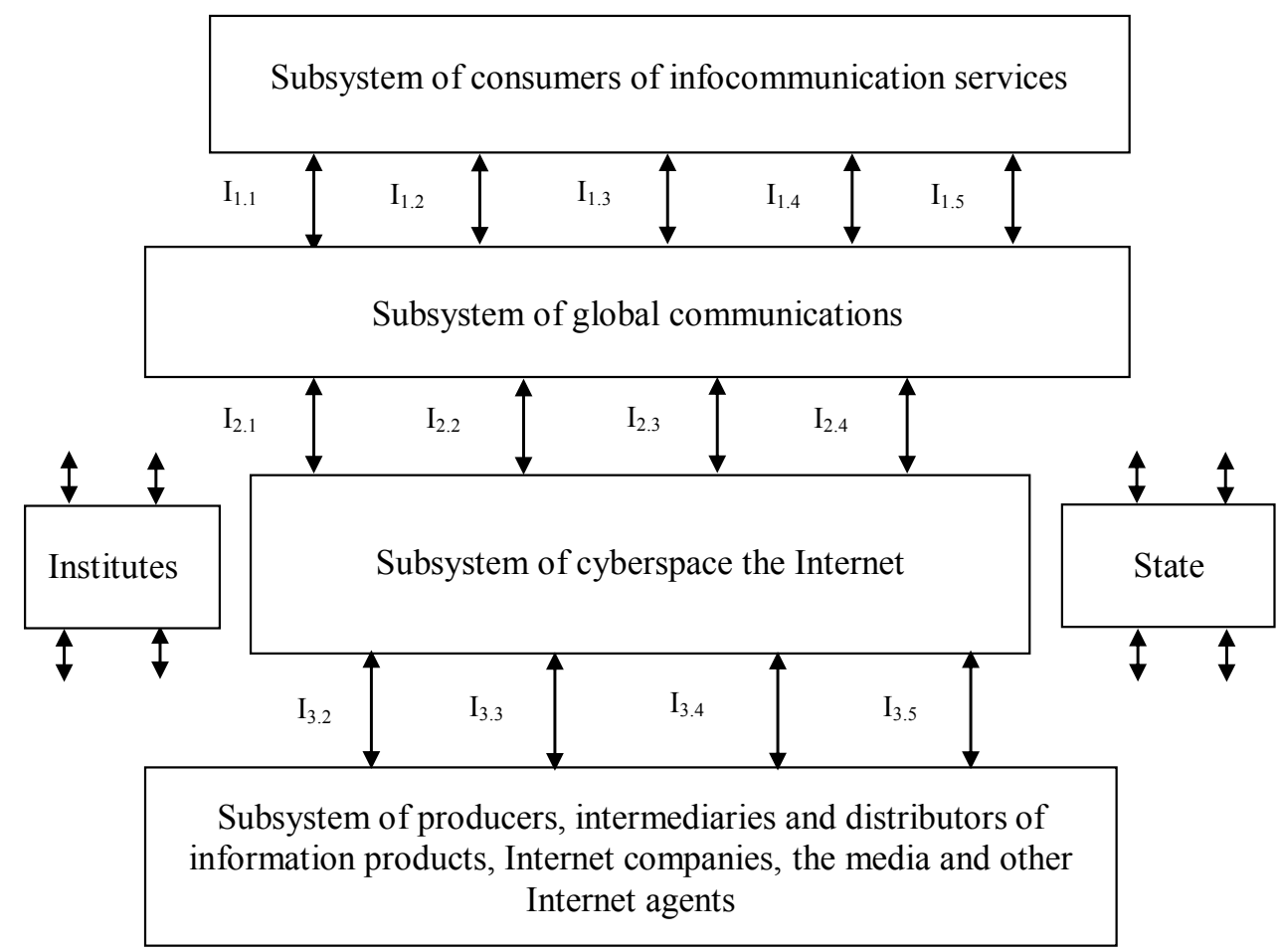

Fig. 1. The system model of modern markets of infocommunication services Own development of the authors 
$-I_{1.2}-$ information on the provision of video services (video communication of the operator's client with any other client via a communication channel), advertising;

$-\mathrm{I}_{1.3}$ - information on the provision of infocommunication services to consumers from Internet companies through a communications enterprise channel, advertising;

$-\mathrm{I}_{1.4}$ - information on the provision of infocommunication services from the Internet media through the operator's channel, advertising;

$-\mathrm{I}_{1.5}$ - information on the provision of infocommunication services from the communication company (operator), advertising.

Since the provision of infocommunication services can bring additional income, communications enterprises (telecom operators, other telecommunication companies) produce some infocommunication services themselves (Internet TV, various media services and much more) and offer them to their customers (5, p. 20-23).

Global communications subsystem. Almost all currently functioning communication (telecommunication) enterprises (mobile and fixed-line operators, Internet providers and other telecommunication companies) operate in the network of the communication services market.

The information connection of this subsystem and the cyberspace subsystem of the Internet consists in transmitting the received information with permissible distortions and is characterized by the following flows:

$-I_{2.1}$ - information on the provision of digital IT telephony services (voice communication of the operator's operator with any other Internet client), advertising;

$-I_{2.2}$ - information on the provision of video services (video communication of the operator's operator with any other Internet client), advertising;

$-I_{2.3}$ - information on the provision of information and communication services from Internet companies, agents, advertising;

$-I_{2.4}$ - information on the provision of infocommunication services from online media, advertising.

Subsystem of producers, intermediaries and distributors of information products, Internet companies, the media and other Internet agents. This subsystem includes a continuously expanding set of various enterprises: Internet companies; producers of information products; enterprises replicating information products; enterprise intermediaries; media companies and many other internet agents. The most distinct from the traditional markets are the markets of information products producers. Information products are produced by professionals with knowledge using new and new information technologies. The producers of information products, as a rule, are not engaged in their further distribution, these functions are carried out by enterprises replicating these products. The variety of information products, a fairly large and steadily growing demand for them caused the emergence of many different enterprises of intermediaries and Internet agents.

The information communication of this subsystem and the cyberspace subsystem of the Internet is characterized by the following flows:

$-\mathrm{I}_{3.2}$ - information on the provision of various video and media products;

$-I_{3.3}$ - information on the provision of infocommunication services from Internet companies to consumers;

$-\mathrm{I}_{3.4}$ - information on the provision of information and communication services from the Internet media;

$-I_{3.5}$ - advertising.

In this case, advertisements are allocated in a separate stream, since in the modern Internet, advertisements come to the Internet user, regardless of whether he is a consumer of infocommunication services or simply connected to the Web.

State. At present, the tasks of state bodies in the market of infocommunication services are not clearly defined. These markets are global, national borders of these markets do not exist. The laws on the regulation of telecommunications in various countries determine the rules for the functioning of operators and providers only in the national market for telecommunications services. This problem needs research and legal support [6, p. 99].

Institutes. The introduction of institutional norms and rules, expanding the influence of both state and public institutions is promising in the markets of infocommunications services. Some institutions are already beginning to function. This problem also needs research and legal support [6, p. 99].

Conclusions. The authors have proved the possibility and feasibility of using the system approach for researching the markets of infocommunication services in the context of technological innovation. A system model of modern infocommunications has been proposed and substantiated. The following subsystems were investigated: information and communication services consumers; global communications enterprises; producers, intermediaries and distributors of information products (Internet companies, media companies and other Internet agents), as well as the use of global cyberspace on the Internet in the interests of producers and consumers of infocommunication services. 
The originality of the author's material of the article consists in substantiating the use of a system approach to researching the markets of infocommunication services, designing a system model of modern markets for infocommunication services, identifying and studying subsystems.
The priority direction for further research may be to detail the allocated subsystems: infocommunication services consumers; global telecommunications enterprises; producers, intermediaries and distributors of information products and clarification of links between them

References:

1. Schwab, K. (2016). Chetvertaya promushlennaya revoliutsiya [The Fourth Industrial Revolution]. URL: https://eksmo.ru/book/chetvertaya-promyshlennaya-revolyutsiya-ITD819325 [in Russian].

2. Bagorka M.O. (2017). Systemnyy ta sytuatsiynyy pidkhody yak metodolohichna osnova formuvannya marketynhovoyi stratehiyi ekolohizatsiyi ahrarnoho vyrobnytstva [Systematic and situational conditions are based on the basis of the form of marketing strategy of agricultural agribusiness]. Problems of the system approach in economics, 4 (60), p. 28-33 [in Ukrainian].

3. Grinenko, A.Yu. (2017). Systemnyy pidkhid do doslidzhennya zahroz ekonomichniy bezpetsi Ukrayiny $v$ transformatsiynomu periodi [System approach to the study of threats to Ukraine's economic security in the transformational period]. Problems of the systemic approach in the economy, 6 (62), p. 19-24 [in Ukrainian].

4. Kuzovkova, T.A. \& Tymoshenko, L.C. (2016). Analiz i prognozirovanie razvitia infocommunikacatsiy [Analysis and forecasting development of infocommunications]. Moscow: Goriachaia linia-Telecom [in Russian].

5. Strii, L.A., Mamedov, M.A., Pustamov, O. M. (2015). Marketing predpriiatii infokommunikatsii: sovremennye vidy marketingovoi deiatel'nosti [Marketing of infocommunications enterprises: modern types of marketing activities]. Saarbrucken: LAP Lambert Academic Publishing [in Russian].

6. Golubev, A., Striy, L. \& Zakharchenko, L. (2015). Ekonomika i upravlenie na predpriatii: osnovnue tendtncgii razvitia [Economy and Management of an enterprise: the main trends and problems of development]. Saarbrucken: LAP Lambert Academic Publishing [in Russian].

7. Striy, L., Yepifanova, I., Orlovskiy, B., Sobirov \& Miralibekov, B. (2017). Market of communication and internet services: research of competitive environment. Technology audit and produchtion reserves, 5/5 (37), p. 20-24 [in English]. DOI: http://dx.doi.org/10.15587/2312-8372.2017.113276.

8. Striy, L., Orlov, V. \& Zaharchenko L. (2018). Modern infocommunications: research of factors affecting innovative development. Economic journal Odessa polytechnic university, 1 (3), p. 62-68. URL: http://economics.opu.ua/ejopu/2018/No1/62.pdf [in English]. DOI: 10.5281/zenodo.1304084.

9. Striy, L., Mohammad, H., Pavlenkov, E., Korniychuk, A. \& Rustamov, O. (2018). Features of enterprise activities on the modern global market / Actual scientific research: Collection of scientific articles. Editoria di Modena, Rome, Italy, p. 77-62 [in English].

10. Striy, L., Golubev, A. \& Rustamov, O. (2012). Model vzaimodeystviya rynkov ekonomiki infokommunikatsionnykh uslug [Model of interaction of markets for the economy of infocommunication services]. Sovremennyy nauchnyy vestnik. Nauchno-teoreticheskiy $i$ prakticheskiy zhurnal. Seriya: ekonomicheskiye nauki, №21 (133), 85-91 [in Russian].

11. Striy, L., Zakharchenko, L. \& Golubev, A. (2014). Rynkovi mekhanizmy i struktury ekonomiky infokomunikatsiynykh posluh [Market mechanisms and structures of the economy of infocommunication services]. Ekonomika: realiyi chasu: naukovyy zhurnal, 1 (11), 134-141. URL: http://economics.opi.ua/files/archive/ 2014/nl.html [in Russian].

12. Striy, L., Zakharchenko, L. \& Golubev, A. (2016). Setevaya organizatsiya rynkov infokommunikatsionnoy otrasli [Network organization of the markets of infocommunication industry]. Naukovyy visnyk Khersons'koho derzhavnoho universytetu. Seriya: ekonomichni nauky, 16, part 4, 43-47 [in Russian].

13. Stryi, L.A. (2000). Marketingovoye upravleniye na rubezhe XXI stoletiya [Marketing management at the turn of the XXI century]. Odessa: Astroprint [in Russian].

14. Philosophical dictionary. Ed. I.T. Frolov. 5th edition. (1987). Moscow: Politizdat [in Russian]. 